\title{
Kutilové identity - Sběrači idejí - Stopaři. Ke vztahu historie a systematiky sociologické teorie po Robertu K. Mertonovi
}

\author{
Identity Engineer - Collector of Ideas - Trace-Tracker. \\ On the History and Systematics of Sociological Theory \\ After Robert K. Merton
}

\author{
Frank Welz
}

\begin{abstract}
For the history of sociology not to lose its relevance to the discipline, it should not be understood as a biographically oriented parade of recognized and forgotten classics, but rather complement sociological theory. Writing upon these premises, the historian of sociology would cease to act as the discipline's identity engineer who, considering the competitive field of theories and subjects, conservatively serves sociology to find and stabilize its historical identity. Furthermore, s/he would no longer operate as collector of ideas in search in the history of sociology for concepts of sociological analysis that were abandoned at some point, and in doing so, would cease to pursue the objective of critically undermining the dominating paradigms in contemporary sociology. On the contrary, since the 'historic turn' in the philosophy of science, the historian of sociology has to take up a trace-tracking role. In contrast to Robert K. Merton's stance, the theory and history of sociology should not be understood as two separate ventures. Rather, the genealogical exploration will lead to a historical epistemology of disciplinary paradigms that emphasizes that theoretical paradigms must be analyzed within the social context of their genesis. Such an approach would enable us to systematically identify the prerequisites and range of contemporary theoretical paradigms. Beyond Merton's former analysis, theory construction in sociology requires that systematic and historical reconstructions go hand-in-hand.
\end{abstract}

KEYWORDS history of sociology, sociological theory, philosophy of social science, Thomas S. Kuhn, Robert K. Merton

K čemu je historie sociologie? Jsou životopisy učenců pro sociologický výzkum vůbec nějak důležité? Potřebují učební osnovy chronologické přehledy dogmat? Je vlastně historie sociologie ještě relevantní z hlediska svých současných úkolů (Peel 1978)?

Výchozí otázkou mého příspěvku je, zda po dosažení současné úrovně třídění a pozice sociologie její systematika ještě potřebuje historii, či zda jedna druhou degraduje

Sociálni studia. Katedra sociologie FSS MU, 1/2012. S. 75-91. ISSN 1214-813X. 
na prehistorii. Mé pojednání přitom rozlišuje tři př́istupy $\mathrm{k}$ dějinám disciplíny, které jsou rovnoměrně odstupňované podle specifického pojetí vztahu historie a systematické konstrukce teorií. Př́spěvek proto $\mathrm{v}$ zásadě slouží otázce, jak sociologie zachází se svými dějinami, a pokouší se na tuto otázku podat systematickou odpověd'.

Ve třech krocích se budu věnovat možnostem, jaké máme $\mathrm{k}$ dispozici při zodpovídání této otázky a které jsou široce zastoupeny v publikační praxi oboru, přičemž v pohledu na současnou situaci sociologie vyzdvihnu právě třetí možnost, již v současné době považuji za nejdůležitější. Nejdřive stručně shrnu jednu z variant legitimizování historie sociologie, v jejímž důsledku vystupuje historik sociologie jako jistý kutil identity svého oboru, a slouží tak cíli zformovat nejprve jednotlivé tradiční linie teorie (1). Dalším tématem bude v současné době nejrozšířenější pojetí zaměřující se na naši ideovou minulost: zájem chápat vědce jako sběrače idejí a dějiny sociologie jako nevyčerpatelný, neustále stimulující repertoár konceptů a idejí (2). Poté proti těmto dvěma pojetím postavím třetí archetyp analýzy dějin disciplíny a prohlásím: Teorie a dějiny sociologie se komplementárně doplňují tehdy, když se historik/historička sociologie vydá po stopách a jakožto genealog/genealožka sleduje historickou epistemologii, která reflektuje paradigmata současného teoretického aparátu v jejich utváření, a tím dosahuje hloubky a ostrosti (3).

Úvahy povedou k tomu, že se rozšířený vzorec zdůvodňování důležitosti historie idejí pro současnou konstrukci teorií ocitne vzhůru nohama. Sociologické zpracování dějin disciplíny je prospěšné ne proto, že zároveň s ním mohou být (znovu)objeveny ztracené ideje nebo rané náznaky dnešních pohledů, a tím rozšířeny konceptuální možnosti sociologie. Mojí tezí je opak: Zkoumání historie sociologie může a má umožnit selektivnější porozumění dnešním teoriím, protože na znalost společenských poměrů a kontextů je odkázána také současná sociologická práce, ve které a pro kterou byly vyvinuty otázky a nástroje myšlení, které ji jako celek zformovaly.

Můj argument se opírá o vývoj v rámci filosofie vědy, která v 60. letech 20. století $\mathrm{z}$ tehdejší mainstreamové pozice à la Robert K. Merton přššla k postempirickému chápání vědecké praxe. $\mathrm{V}$ napětí mezi těmito dvěma póly budu analyzovat možné způsoby chápání historie a sociologické teorie. Podle Mertonova vlivného pojetí byly historie a systematika sociologické konstrukce teorií dlouhou dobu považovány za oddělené počiny (Merton 1967). Jejich míšení jen podporuje zmatek, argumentoval Merton, protože nekritická úcta před mysliteli minulosti nepřispívá $\mathrm{k}$ adekvátní sociologii současné společnosti. Z pohledu historizující filosofie vědy, jak se etablovala po Mertonovi a systematicky rozvinula např́č obory u autorů jako Thomas S. Kuhn (1962), je oproti tomu možné jiné pojetí, jehož kontury bych zde rád načrtl.

Nejprve je nezbytná ještě jedna poznámka. Můj zájem patří příspěvku, který může historie sociologie přinést teoretické diskusi. Výslovně nejde o otázku, jež je jinak nasnadě, tedy jak je třeba tuto historii psát. Bezpochyby by z pohledu sociologie bylo třeba přistupovat k veškeré historii oboru „,sociologicky“; nikoli logocentricky, nejen historicky nebo biograficky. Samo sebou by historie sociologie tudíž musela zohledňovat teoretické směry a školy, podmínky jejich práce a poznání, stejně jako procesy institucionalizace, interdisciplinární vývoj, národní a globální tradice oboru (Lepenies 1981a) a obzvláště souboje konkurenčních paradigmat (Collins 1998). Nemohla by se spokojit s hagiografií velkých mužů nebo 
opisováním tradovaných doktrín. Zcela jednoduše: měla by být sociologická (Jones 1983; Fleck 1999). Zde mě však vztah konstrukce teorií a historie zajímá poněkud zásadnějším způsobem. A abych vyloučil všechna nedorozumění, ještě jednou dodávám: Nejde o onu věčnou kontroverzi nad tím, jaká má být adekvátní sociologie, což znamená, jaký má být adekvátní sociologický popis historie oboru. Můj zájem je v tomto ohledu systematický. Zůstávám proto blíže k tématu mertonovské skici ke vztahu dějin a systematiky sociologie - ačkoli s opačným znaménkem.

\section{Kutil identity: Historie sociologie jako prehistorie}

Marx jak známo postavil Hegelovu filosofii „na hlavu“. To umožňuje ,anticipovat" důležité myšlenkové figury našeho klasika. Často jsou teorie minulosti považovány za „důležitá zastavení a programové návrhy“ na cestě ke „získání př́stupu k pojmu sociologie“ (Heckmann a Kröll 1984: 74). V historii sociologie pak v tomto pojetí mohou být hledány „odpovědi na otázky čekající po staletí“, které by se mohly slít v „odtékající řeku, jež se pomalu rozšiřuje“" (Korte 2006: 232) - většinou od Comta až do současnosti (a zde zase po Ulricha Becka; srov. Korte 1992 a 2006). Jedná se přitom o historii nejdříve mlhavých, poté stále jasnějších, čím dál tím bohatěji a obratněji formulovaných idejí: tedy o historii sociologie jako prehistorie vedoucí až k současné teorii. Její historik sleduje nadčasový proud věčných idejí. $Z$ torza dřívějších sociálních věd a pouček dešifruje základní principy vývoje sociologického kladení otázek a uspořádává minulé koncepty jako předstupně současné konstrukce teorií (Jonas 1981, svazek 1: 11). Pokud se podíváme na stále rychleji vycházející základní příručky („úvody do...“) a z nich odvozené úvodní přednášky, učebnice a skripta, vznikající pod tlakem silně standardizovaných koncepcí studia jako důsledek Boloňského procesu, vypadá to, že tento způsob chápání minulosti oboru je dost rozšířen. Je však také správný?

Sázíme-li na pojednání Roberta K. Mertona o historii a systematice sociologické teorie, pak se nabízí jen tato možnost. Za „osudné“ pokládá Merton, citovaný po mnoho let v sociologických časopisech, „směšování současné sociologické teorie s historií sociologických idejí“ (1967; německy 1981: 16). Mertonovy ideje, koncepty, metodologické návrhy k teoriím „středního dosahu“ (Merton 1968) sloužily k regulaci zdánlivě bezbřehé plurality „zastaralých“ sociologických perspektiv prostřednictvím empirických faktů (Turner 2009: 186 a dále). Je neobyčejně důležité, že historie disciplíny nesmí být za takových podmínek hodnocena. Nebot' pokud má sociologická teorie svou adekvátnost sama prokázat ve faktech současnosti, je historická geneze konceptu irelevantní. Dokud je chápána jako výrokový systém vět, které mají být empiricky verifikovány, musí se - z hlediska teorie - studium historie disciplíny jevit jako bezvýznamný počin. Odpovídajícím způsobem se studium dřívějšího užití teorie systematikům à la Merton jeví jako mělký vrt do minulosti, který na světlo současnosti nedopravuje už nic než podobnost mezi současnými a dřivějšími idejemi, aniž by nalézání nebo nenalézání antikvárních předchůdců mělo význam pro otázky teorie. Historie sociologie je podle tohoto zadání relegována na prehistorii: pomocnou vědu. Je nanejvýš novým polem pro užití sociologických metod analýzy (které Merton bezpochyby chtěl podpořit; oproti jakoby reportážnímu řazení souhrnů kdysi významných idejí). Pokud je přesto k dispozici 
biografická přehlídka mistrů oboru, je za předpokladu striktního oddělení systematiky a historie teorie považována spíše jen za ústupek zájmům začátečníků - a za důsledek konkrétních učitelských návyků. Jen dokud dominovalo empiristické chápání teorie, které mohlo odhadovat pokrok vědy prostřednictvím kumulativního sesbírání empirických nálezů, mohla být historie vědy nahlížena jako kontinuální proces vedoucí až k současnému tvaru teorie, jež je stále adekvátnější skutečnosti. Podle Mertona (1981: 42) by sociologické prŕístupy neměly být chápány jako „konkurující si myšlenkové systémy“, ale raději by měly „být prezentovány jako př́íspěvky do sborníku“. Přesně takovéto úrovně vědy, legitimované sebou samou, neustále kumulující výsledky a kráčející vpřed, sociologie dosáhla podle Mertonova současníka a učitele Talcotta Parsonse (1959) konečně na sklonku 50. let 20. století.

Pod konceptuální záštitou sociologické odluky historie a teorie přichází pro status klasických sociologických konceptů, tzv. „big questions“, otázek po vytváření industriální společnosti a kultury moderny, v úvahu dvojí: Bud’ se ještě stále hodí k popisu současnosti, anebo se k němu již nehodí. Je zjevné, že se praxe výzkumu ve svých empirických časopiseckých publikacích usnesla na tom druhém a že se knižní trh se značným počtem specializovaných autorů, kteří vždy nově interpretují, shrnují a komentují „klasiku“, rozhodl pro to první. Pokud má ted' dokonce i v chápání tohoto prvního postoje $\mathrm{k}$ historii teorie přibýt ještě relevantní funkce, pak nemůže tkvět $\mathrm{v}$ prŕípravě nebo prohlubování teoretických otázek. Ale $\mathrm{v}$ čem jiném?

Rozdělením úkolů historie a teorie sociologie je sledován jiný cíl. Dokonce i jako určitá prehistorie plní odborná historie, ačkoli vnímána marginálně, specifickou úlohu: účelem resumování a tradování myslitelů a konceptů minulosti je pak v prvé řadě stabilizace historické identity sociologie, a sice v rámci konkurence oborů. Rekonstrukce prehistorie slouží jako upomínka minulosti disciplíny, na kterou se členové vědecké komunity mohou odvolat (Lepenies 1981b). Nebo je minulost „zápolením o ,správné chápání sociologie“, na základě kterého pak mohou být představeny v současnosti „správné“ „,základní rysy sociologie“ (Büschges, Abraham a Funk 1995: 1). Aby bylo možné vytyčit vlastní území mezi společenskými a př́rodními vědami, mezi historií a filozofií, je třeba vlastní identity: starých i „aktuálních“ klasiků sociologického myšlení (Käsler 1976, 1978, 2005). V zakládající fázi byla Durkheimovým řešením tohoto problému obrana hlavního předmětu oboru: pohled na společnost jako na věc (Durkheim 1984: 115). Konstrukce „vlastní“ minulosti je jiné řešení. V prvé řadě bývají přizváni již etablovaní klasikové, aby byla současnému konceptu propůjčena autorita. A toto platí obzvláště ve zde uvedeném př́ípadě (nebo právě pro něj), podle nějž může historická perspektiva k systematické perspektivě teorie přispět jen pramálo. V tomto scénáŕi proto historie sociologie nalézá svou funkci v kondenzování a zabezpečování současné sociologie. V čem potom spočívá úloha historika sociologie?

Pokud je zde historie pouhou prehistorií a její rozpracování slouží jen institucionální vážnosti, $\mathrm{k}$ systematice nijak nepřispívající stabilizaci jednoty disciplíny, stává se vypravěč historie oboru kutilem identity. Kutil odkrývá, nebo lépe vytváŕí historický proud idejí, zasahující až do současnosti. Nit idejí, již konstruuje, „velký řetězec idejí“ Arthura O. Lovejoye (1985), zakládá specifickou identitu v současnosti používaných konceptů. Je to konzervativní práce. A může působit anachronicky v časech (post)moderní plurality idejí (Lyotard 1986, Luhmann 1991). Přesto nemůže být „stabilizační““ úloha v rámci disciplinární 
institucionalizace dostatečně oceněna. Zatímco například zásadního díla Maxe Webera Hospodářství a společnost se v letech 1922 až 1947 prodalo méně než 2000 výtisků (Käsler 1988: 209), prodá se dnes na masovém trhu ve Spojených státech odhadem 800000 exemplářu základních sociologických př́ruček - za jeden rok (Hamilton 2003: 282). Jakkoli se kutilům identity sociologie a jejich „školám“ může dařit v učebnicích nabízených na masových trzích zakotvovat specifické ideje, přispívají zcela jistě fakticky k tomu, že se pozornost zájemců o studium upírá k sociologii jakožto koherentní disciplíně, která se nikoli bez jasných kontur, a tudíž bez posloupnosti, rozpadá v fragmentovanou záplavu popisů.

Takovíto kutilové se však upisují úkolu, který je stále obtížnější plnit. Jsou pro to dva důvody: první je intelektuální a druhý čistě kvantitativní. Za prvé lze namítnout, že „,prehistorie“ sociologie tak, jak byla popsána výše, může být psána jen z pozice „vítězư“. Taková „whigovská interpretace dějin“, jak tento fenomén poprvé popsal Butterfield (1931) (aby charakterizoval prezentismus historiků, tedy psaní historie nikoli ze strany katolíků a Toryů, ale z pozice protestantů a Whigů, rané skupiny v anglickém parlamentu), musí nyní v rámci historie idejí předpokládat narůstající racionalitu, která je v mulitlaterálním, mnohotvárně a různě popisovaném světě čím dál tím méně srozumitelná - což zde rovnou vede k druhému argumentu: Nebot' - za druhé - enormní rozrůstání odborné obce si institucionálně vynucuje pokračování vnitřní diferenciace, ve které jsou „vítězné“ racionality a za identitu ručící zakládající otcové o to méně přesvědčiví, čím více od nich zaznívají důvody pro distinkci. Je-li nějaký obor kvantitativně malý, jeví se jeho historie jako jednotka; pokud jeho vydělování postupuje vpřed, roztř́šstí se jediná historie oboru na vícero historií. Pokud ale existuje mnoho minulostí, mnoho cest a mnoho hrdinů nějaké vědy, pak na poli současných konkurenčních teorií klesá reputaci zajišt’ující hodnota scholasticky-komentující nebo biograficky-vyprávějící historiografie idejí stále hlouběji. A má-li tato dříve důležitá hodnota plnit svou funkci, není divu, že se mnoho prací o historii sociologie jakožto o určité prehistorii, takř́íkajíc ,se zvláštním přihlédnutím k biografickým aspektům“ tak, jak vycházely až do 80 . let 20. století, jeví z dnešního pohledu jako matné a nesociologické úsilí (Mozetic 1995: 3).

\section{Sběrač idejí: Historie oboru jako arzenál pojmů}

I proto se dnes značně rozšiřuje jiný pohled na funkci dějin idejí, vytrvale konkurující výše zmíněnému pojetí. Historie sociologie není v dnes převládajícím chápání publikační a výukové praxe pouze služkou teorie, jež má stabilizovat identitu oboru. Znakem tohoto druhého pojetí je spíše méně striktní dělení na minulou a současnou konstrukci teorií, než jak je načrtávaly vědecko-teoretické představy à la Merton. Zpracování historie oboru - ovšem stejně jako dílčí výklady národních sociologií, které se jinak nedostaly do hledáčku odborné obce (např́klad Möbius a Peter 2004; Welz 2009) - pak může z hlediska konstrukce teorií opět získat zcela jasný význam. Historie sociologie se pak jeví, jak je to formulováno ve známém pojetí Friedricha Jonase, ,jako organon, kterým se odemykají různé možnosti interpretace společenského procesu“" (1981, svazek 1: 12). Tato formulace je ještě výraznější při pohledu zpět uskutečněném přímo ze systematického hlediska, jako např́klad u Richarda Müncha, který vychází ze „zásadního přesvědčení, že klasikové jsou ještě dnes aktuální a podrobná analýza jejich myšlení je nevyhnutelná i pro současnou sociologickou teorii““ 
(Münch 2002: 9). V neposlední řadě to v učebnicích vzniklých pro potřeby výuky odpovídajícím způsobem znamená, že „texty klasikư“ si uchovávají ,životnost [...] v míře, v jaké se o nich diskutuje“ (Vester 2009: 14). Tímto způsobem je historie sociologie legitimizována mnoha svými provozovateli. Nebot' znovudobytí minulosti zde nabývá nového smyslu: jeho účelem je odkrývat minulost oboru jakožto nevyčerpatelnou stavebnici ideji pro současné úkoly.

Jak tedy v této variantě přesněji funguje pohled zpět na minulé myslitele a myšlenky? Do jaké míry je historie sociologie podle této varianty relevantní pro sociologii jako odbornou disciplínu? Její významnost už netkví v možnosti ustavení historické identity. Spíše leží v rozšsiřrení myšlenkového spektra umožňujícího zpracování dnešních otázek. Historie sociologie se vyplatí při péči o arzenál pojmů dnešní praxe a při jeho rozšiřování. V prototypické formulaci George Ritzera, od kterého pochází celosvětově nejčastěji používaná učebnice teorie a rozličné ,encyklopedie“ základů sociologie (Ritzer 2008), pak prochází historie sociologického myšlení v syntetizující manýře přes metodu „metateoretizování" $\mathrm{k}$ novému „more integrated sociological paradigm" (Ritzer 2008: A-1 a následující, A-12; srv. Ritzer 1992). Místo o stabilizaci identity oboru jde o její zkapalnění. Jde o variaci a tzn. o otevření tehdejšího korpusu teorií, a tedy možností sociologického popisu, jež jsou dnes k dispozici. To platí tam, kde se připomíná ten či onen zapomenutý náhled. Platí, kde to lze ukázat, že dosud marginalizované postavy razily vývoj sociologického myšlení větší měrou (Honegger a Wobbe 1998), než si to obor doposavad přiznával atd.

Hned prvním skvělým př́kladem je zde pozdní, do raných 70. let 20. století datované přijetí Karla Marxe mezi prvořadé klasiky. Jak známo, vlivný prŕspěvek Talcotta Parsonse k tomuto kanonizování Marxe ještě nevedl (Parsons 1968). Jiným př́́kladem je - pozdě a navíc nejprve v amerických učebnicích (Macionis 1993: 21) - instalace Harriet Martineau (1802-1876) do galerie předků, důležitých producentů idejí. Markantní i sociologicky pochopitelné je, že na její „objev“ v raných 90. letech 20. století, podle jednoho z autorů učebnice, působil více sociální tlak než dílo samotné, které bylo desítky let předtím pokládáno za žurnalistické (Hamilton 2003: 295). V př́ipadě Marxe, a dokonce v př́padě přijetí tak zvané Svaté trojice Marx-Durkheim-Weber do celosvětového učebního kánonu sociologie, se zhodnocení uskutečnilo taktéž s velkým časovým odstupem.

Odpovídající „,vzpomínka“ v současném záměru existuje tam, kde je historik sociologie - v rouše s mnoha fasetami - pokládán za „ochránce kanonické moudrosti“: např́klad aby prosadil intelektuální dědictví jako jistý způsob morálního svědomí tady a ted' (Käsler 1999). Pro mnohé leží to naprosto nejlepší ze sociologie dokonce v minulosti (Turner 1998: 10), protože ze současnosti oboru, jež je nyní více zaneprázdněna sama sebou, zmizely velké otázky, a tudíž vážné, danou společenskou zkušeností formulované potřeby, a byly nahrazeny výzkumem sloužícím jen kariéře vědců. Pokud se popis vývoje a utváření oboru ze strany jeho protagonistů a administrátorů už nemohou soustředit kolem adekvátní kognitivní ústřední postavy, ale naprosto nuceně sociologicky v institucionálních bojích o oblasti vlivu a v půtkách skupin o pozornost, pak musí kritici, jako Stephen Turner (navíc v souvislosti se skrznaskrz kvantifikovanou americkou sociologií), dojít k závěru, že „lidé, kteří mají zodpovědnost za její současnou podobu, mají dobré důvody obávat se historiků“ (Turner 1998: 10). 
Dokonce takový systematik jako Talcott Parsons vítá odpovídající návrat ke klasikům, který přinese něco nového a nechá se od předků poučit (Parsons 1981: 189 a následující). Jeffrey C. Alexander pohlíží na kognitivní dimenzi sociologie jinak než Merton, a srovnatelně $\mathrm{s}$ Ritzerem se právě proti rigidnímu rozprostírání hranic mezi historií a systematikou v aktuální americké sociologii zastává syntetizujícího přístupu k oborovému repertoáru idejí (Alexander 1988: 77). Pro mnohé směřuje takový návrat zpět nejen k jednotlivým idejím nebo pojmům, ale vlastně k celým př́stupům, které byly už kdysi prohlášeny za zastaralé (Lenski 1970). Nebo slouží trvalé komunikativní reprodukci školních kontextů jako v případě Chicagské školy (Plummer 1997), jejíž kanonizace, stejně jako je tomu u ústředních klasiků, není ukotvena. Přestože sám zaměřen proti prezentistickému užití minulosti sociologie, ukazuje Charles Camic $(1979 ; 1981 ; 1987)$, podle celé řady prací jeden z význačných zástupců právě sociologické, tzv. nové historie idejí, co ještě může být objeveno v dílech dokonce často zkoumaných klasiků: dosud přehlížené ,myšlenky skryté v pozadi jejich textů“ (Camic 1986: 1043; kurzíva $F$. W.). To ovšem může být důležité jen tehdy, když vědecko-teoretické chápání už nebude vycházet z kumulativního nabývání vědění, jak se předpokládá v Mertonově ontologickém empirismu, ale stůj co stůj z koherentních konceptů, které lze prrijímat a opouštět a které tedy teprve osmysln̆ují ono znovuobjevení (Skinner 1985).

Co je tedy za těchto podmínek úkolem historika sociologie? Jako kutil identity podléhá konzervativním závazkům. Jakožto náruživému sběrači ideji mu naproti tomu připadá kritická role. Proč by také jinak naučná a teoretická díla z historie disciplíny měla být doplňkem k současnému teoretickému aparátu? Má-li mít z pohledu „kritické“ dělby práce historie a teorie sociologie studium historie disciplíny více než jen propedeutický smysl, pak musí být účelem sociologicko-historického cvičení nejen doplňovat, ale také obohacovat a vylepšovat dominující paradigmata současnosti. Neméně významné pak je podkopávat a dekonstruovat převládající nástroje myšlení, vynášet na světlo domněle skryté další varianty, legitimizovat je atd. Jedním takovýmto proslaveným pokusem byla např́klad v roce 1975 ,de-Parsonizace Webera“ - útok Cohena, Hazelrigga a Popea na Parsonsovu tehdy dominantní sociologii.

Nebot' zatímco si zástupci institucionálně etablovaných teoretických škol, jako systémové teorie, Habermasovy komunikační teorie nebo parsonsovského funkcionalismu, mohou dovolit číst historii idejí sociologie jako uzavřenou staroevropskou minulost (Luhmann), jako vývoj směřující k pokusu o napojení (Habermas) nebo jako sklad materiálu syntézy (Parsons), pro obránce marginalizovaných pojetí to vypadá jinak. V kontrastu vůči proponentům vlivnějších pozic, kteří „to své“ hájí jako jediný možný program teorie (srv. Braun 2008), je sociologicky vzato okrajovým proudům bližší klonit se k relativismu teorie (Wallerstein 1997), na základě kterého skýtá minulost disciplíny př́ležitost k znovuobjevování či podkopávání konkurenčních škol. Kdo nesouhlasí se současným trendem hlavního proudu, jde zpět do historie společenského myšlení - anebo hledá v jiné disciplíně. Z pohledu celku proto sběrač idejí každopádně působí kriticky, dokonce i když pomýšlí na „čistě historickou“ práci.

Pro něj je historie sociologie inventářem konceptů. Vedle pojmů zahrnuje arsenál idejí výzkumu, takřka surogát hodnot, které podle Maxe Webera výzkumu „[ukazují] směr, kterým se pojmotvorba v oblasti kulturních věd v daném př́padě vydá“ (Weber 1985: 155). Takto chápaná historie sociologie má skutečně neocenitelný význam pro výuku oboru. Nebot' bez povědomí o idejích, o tom, co by vůbec mohlo být předmětem výzkumu, bez znalostí dosud 
používaných pojmů a perspektiv by výkony noviců odborné obce $\mathrm{v}$ disciplíně jen živořily jako mnohokrát opakované objevení ,nové sociologické Ameriky“ (Sorokin 1964: xviii-xix). Bezesporu právě proto zůstává historie idejí i s takto rozdanými kartami zcela nepostradatelnou pro účely vzdělávání. Avšak jak si stojí její systematická relevance?

Ve formě narativních př́běhů o postavách z minulosti je její věcný přínos sporný. Přesně vzato to ovšem platí také při pojetí historie oboru jakožto arzenálu idejí. Koneckonců je to už několik desetiletí, co snahy o prosazení sjednocené vědy nebo př́lliš úzké, až moc z ducha doby pramenící diagnózy společnosti, měly být „kriticky“ zmařeny pohledem zpět na ztracené historické koncepty teorie společnosti. Místo toho nabízí intelektuální krajina současnosti ve velkém obrázek libovolnosti, který už nevystihuje otázka frakčních sporů, které byly v německy mluvící sociologii sedmdesátých let (a i předtím) vyřešeny (Hondrich a Matthes 1978). Potud se zdá, že někdejší nutnost „kritické funkce“ historie sociologie, která vyhodí do povětří nepřeberné možnosti současné př́liš monolitické sociologie, už odezněla. Zdá se to být spíše naopak. Odpovídajícím způsobem se od 80. let 20. století nově nabízí otázka po smyslu a účelu studia a výzkumu historie disciplíny.

\section{Po stopách historické epistemologie: Ke komplementaritě systematiky a historie sociologie}

Proto je nutný třetí přístup, který se postaví novému úkolu stojícímu před disciplínou a její historií, jak ukazuje pohled na vývojové fáze sociologické teorie od roku 1945. Konjunktury daných historických př́stupů nakonec korespondují s variujícími stavy vývoje teorií. Na závěr nejdř́ve načrtnu kontury současného stavu problému (a). Dále se budu zabývat teoretickými východisky, která vyloučila empiristická pojetí kumulativního získávání vědění, tzn. prríspěvkem Thomase $\mathrm{S}$. Kuhna (b), a na tomto základě bude možné založit novou souhru teorie a historie teorie (c).

a) Sociologie po roce 1945 se zhruba dělí do tří fází: Nejdříve šlo o novou konstituci oboru. Strukturální funkcionalismus poskytl vůdčí teorii, empirický výzkum poskytl dominantní praxi. Právě tak se v institucionalizování sociologie jako odborné disciplíny podařilo dosáhnout prvního stupně zralosti (Parsons 1959). Po ní následovala fáze konfliktu. V době od roku 1965 asi až do roku 1980 docházelo ke smíru konkurenčních teorií: vrcholná fáze návratu zpět k již ustaveným nebo ještě ustanovovaným „klasikům“. Tato fáze vyústila nakonec $\mathrm{v}$ dodnes trvající periodu mírové koexistence heterogenních teorií a škol. Na rozdíl od ekonomie, ve které jeden myšlenkový model povýšil na konsensus, je v sociologii akceptován pluralismus teorií. $\mathrm{Na}$ jedné straně se jedná o periodu beze sporů. Na straně druhé je současná fáze charakterizována rostoucím teoretickým fragmentováním, které všude vyvolává kritiku. ${ }^{1}$

Zde použitou heuristickou periodizaci navrhl Richard Kilminster (1998). Co se týče bezprostřední současnosti, dominuje ovšem v jeho pohledu centripetální tendence k teoretické syntéze. Centrifugální síla vedoucí k fragmentaci je pro Kilminstera již opět na ústupu (1998: 167). Také Martin Albrow vidí na obzoru novou syntézu ve formě nového dominantního paradigmatu. Změněná 
Nejprve musel přechod do tohoto současného stadia sociologického vývoje teorie působit jako osvobození. Nekonečné obhajování, exegeze a zdlouhavá ujišt'ování byly stále zbytečnější. Odborná obec se rozrostla, velikost jednotlivých referenčních skupin se zmenšila a zprvu jen polemické ,,anything goes“ filosofie vědy Paula Feyerabenda se staly zcela praktickou realitou (Feyerabend 1976, Weingart 1984). Právě v tomto duchu je od postmoderního přitakání „radikální pluralitě“ (Welsch 1987: 4), tedy od osmdesátých let, v módě historizující relativizování nejrůznějších teorií. Odpovídajícím způsobem se etablovalo mnoho více či méně rovnoprávných hlasů, takže bohatství variací nutné pro další produktivní vývoj sociologie je bezesporu dané. Od etnometodologicky a fenomenologicky založených teorií jednání, přes kritiku a teorii praxe, teorii racionální volby, systémovou teorii a další syntetizující koncepty až k sociobiologii mohly jednotlivé soupeřící komunity v mírové koexistenci budovat své vlastní pracovní kontexty a publikační kanály. Namísto neproduktivního smiřování teorií se tak dostala ke slovu praktická přičinlivá práce a empirický výzkum včetně střednědobého cíle: postupné profilace oboru a kariéry.

Tento úspěch ovšem něco stojí: fragmentaci teorie. Často nezůstávala bez povšimnutí. Např́íklad výzkum Lorda a Sandersona dokumentuje na základě dat severoamerické odborné obce nejen heterogennost kolujících orientačních vzorů a teoretiků, mezi nimiž představují Habermas, Bourdieu, Giddens a Goffman nejvíce ceněnou velkou čtyřku. Zřetelně dokládá také „eklekticismus“ jako nejrozšířenější „teoretickou“ perspektivu vedle symbolického interakcionismu a teorie konfliktu, jak si ji podle předložené studie přivlastňuje každý čtvrtý sociolog (Lord a Sanderson 1999: 60). Co však pro vydělování oboru bylo nezbytné, je pro systematiku jeho kognitivního jádra problematické. Nebot' na odvrácené straně úspěšného růstu sociologie se v její současné fázi nachází dvojí: Problematické v pohledu na její veřejnou profilaci je, že se už sotva lze ptát na kontext disciplín různých sociologických směrů. A problematické je mezitím také to, že myšlenkový koncept „sociologie“ celkově ztratil na své dřivější přitažlivosti (Dahrendorf 1996).

Pokud nyní již dlouho pozorovaná krize sociologie není krizí její produktivity a rozšiřování, ale krizí její kognitivní integrace, „krizí teorie“ (Gouldner 1974, Luhmann 1984: 7), pak je pohled zpět na historii sociologie v současné době důležitý z teoretických důvodů. Jinde než v konceptu Roberta K. Mertona už vưči sobě historie a teorie sociologie nestojí v protikladu. Spíše může jedna druhé napomoci k vyšší produktivitě a dalšímu vývoji. To je tezí tohoto př́spěvku. V tomto směru je zde požadováno třetí pojetí jejich vzájemného vztahu, které v konkurenci s oběma výše představenými variantami nevychází ani ze striktního oddělení ani ze smíšení, ale ze vzájemné odkázanosti: z komplementárního vztahu teorie a historie sociologie. Než půjde o to, jak může být historie požadována s ohledem na krizi teorie, je třeba nejprve výše zmíněnou „tezi kontextuality“ zdůvodnit závažným argumentem.

b) Systematický důvod pro tezi kontextuality je očividný. Pro sociální vědy platí, že „pravda“ má časové jádro. Co na paradigmatech a nastolených problémech tvoří kognitivní

geopolitická situace by toto způsobila, argumentuje Albrow (2004: 48), protože propojené rozhodovací struktury nového multilaterálního světového pořádku konceptuálně vyžadují obnovenou teorii společnosti. 
identitu oboru, nemůže být nahrazeno historickými formami myšlení a společenských předmětů, ze kterých a na kterých se paradigmata tvoří. Čím Hegelova Phänomenologie (1952) vstoupila $\mathrm{v}$ roce 1806 do filosofického rodokmenu, platí o to víc v pojetí sociologie. Nikoli pouze samotný vztah filosofického vědomí a předmětu podléhá historickým změnám, ale také perspektivy filosofie sociálních věd nesou časový index. Nesou index sociální struktury, $\mathrm{k}$ jejímuž popisu byly vyvinuty.

V této souvislosti se na scéně objevuje práce Thomase S. Kuhna (1962). Bylo by možné říci, že jeho teze změny paradigmatu $\mathrm{v}$ analýze vědeckých revolucí zavedla do chápání filosofie vědy ono téma „časové diskontinuty“ oproti empiristické tezi kumulování. Jistým způsobem Kuhn v 60. letech 20. století pro sociálněvědní diskuzi popularizoval kantovsko-koperníkovskou změnu novodobého myšlení a Hegelovu historizaci toho samého. Tehdejší debatu podepíral pohled, že získávání vědecké teorie není kumulativním procesem, ve kterém hromaděním faktu za faktem vzniká vědění. Časy normální vědy, stejně jako Kuhnovo pozorování, ve kterých vědecká práce - prostřednictvím odvolávání se na exemplární příklady teorie, modely a techniky $\mathrm{v}$ předpokládaném myšlenkovém rámci - zápasí o řešení problémů, jsou vždy vystřídány přelomovými dobami, ve kterých se veškerá dřivější nespornost ztratí a radikálně nové pojmové rámce slibují domněle lepší výsledky výzkumu. Právě v takovýchto přelomových fázích vědeckého vývoje se ukazuje, proč Kuhn a s ním veškerá novější vědecká teorie vychází z holistického vztahu mezi teorií a zkušenostmi. Data samotná nemohou volbu mezi teoriemi determinovat. Samotné pojmy vzešlé z pozorování závisejí mnohem více na teoretických předlohách (Hanson 1958). Každý nový pohled na svět přitom není pohledem individuálního vkusu nebo rozhodnutí, a už vůbec není odrazem nastřádaných faktů. Jako paradigmatický rámec chápané vědecké obrazy světa jsou naopak nadindividuální. Představují kulturní struktury, které celé konfiguraci prvků ukazují její místo. Navíc je nelze chápat izolovaně od historického kontextu jejich vzniku, a proto výzkum vědeckých revolucí v Kuhnově pojetí způsobil historizaci filosofie vědy. Právě proto není možné historii a systematiku vědy oddělovat. Kontexty objevování a ospravedlňování vědeckých názorů nelze rozlišovat, jak navrhl Hans Reichenbach (1968: 260) a vedle mnohých jiných převzal také Robert K. Merton. Chápání světa je organizováno figurami myšlení, jejichž časový index teprve musí být „objeven“.

Rozhodující je přitom relační chápání tvorby pojmů. Pojmy by byly chybně a neprávem chápány dekontextualizovaně a empiricky, pokud by byly interpretovány podle nominálního přiřazování $\mathrm{k}$ pozorovaným fenoménům a podle doplňování jednotlivých atributů jako pouhých prostř̌edků k objevování nových objektů. Odpovídajícím způsobem se zakazuje shromažd’ovat je v ideovém arzenálu historie myšlení. Zcela chybně chápána by pak byla kognitivní existence disciplíny jakožto sady nástrojů. Není to žádný „,theory toolbox“ (Nealon a Giroux 2003), jak je přesto často nabízen v úvodních přednáškách analogicky k obvyklému chápání metod. Pojmy jsou spíše historickými objekty, chápanými ve své vztažné soustavě (Skinner 1969). Pokud se takto chápané ,paradigmatické“ koncepty později - zcela nevyhnutelně použijí v nových kontextech, nesmí se zapomínat na kontext jejich vzniku, aby vůbec bylo možné posoudit možnosti a hranice sociologického poznání.

Když se tedy ne my sami řídíme podle předmětů našeho myšlení, ale opačně: když se naše předměty výzkumu řídí myšlením, pak to pro výsledky výzkumu sociologie, které jsou 
odkázány na jazykovou artikulaci, znamená, že jsou stejnou měrou věcí jak jazyka popisu, tak i sociálních okolností. Odpovídajícím způsobem zaujme, které jazyky popisu, pojmy, koncepty, které teorie se používají a jak vznikly (Heilbron, Magnusson a Wittrock 1998). Nebot' jakkoli kontingentně jsou paradigmata a pojmy teorií rozvíjeny a prosazovány, jejich pečet' nese každý výzkum.

c) Přesně v tomto kontextu získává nyní historie sociologie nový význam pro otázku konstrukce teorií. Nebot' co je třeba zkoumat a stále znova rozvažovat, je kdy, kde, jak a proč jsou utvářeny a přejímány koncepty a myšlenkové vzorce. Vědecko-filosofické analýzy teorií a sociologická zkoumání kontextů vzniku musí tedy jít ruku v ruce, prostě proto, že systematické kategorie jsou zároveň historické.

Cíl takovéto kooperace historizace aktuálních teorií a konceptů je přitom blízko. Teorie stanovují sociálně vědeckému výzkumu rámec, který povahu jeho výsledků formuje stejnou měrou jako empirická fakta sama. Ale tyto matrice myšlení nejsou žádným neměnným stavem. Marně čekaly sociální vědy na svého Newtona, který by mohl s konečnou platností definovat jejich teoretický rámec. Taková jistota neměnného fundamentu v historicky uznané skutečnosti neexistuje (Rorty 1979). Ve skutečnosti nejsou filosofémy jakožto sociologické vůdčí ideje nedotčeny sociálním obratem. A zkoumání inovativních idejí v historickém kontextu jejich vzniku je schopno opatřit $\mathrm{v}$ dnešním heterogenním sociologickém arzenálu konceptů virulentní myšlenkové figury indexem kontingence, tím že zpracovávají jejich daný časový zřetel. To nečekaně historii sociologie umožňuje významně nový prínos k teoretické diskuzi, zejména selektivnější a následně lepší porozumění východiskům plovoucím v současném pluralismu teorií, který se novým praktikantům oboru musí jinak jevit jako Mekka naprosté libovolnosti.

Současně se mění role historika sociologie. Místo kutila identity nebo sběrače idejí se zde historik sociologie stává stopařem, impregnovaným teorií. Ve vypátraných zbytcích uplynulého času indikují stopy prezenci, ve které se kř́źží současnost s minulostí. Stopař se školeným pohledem se stává genealogem svého oboru. Zabývá se historickou epistemologii (Margolis 1994: 319, Wartofsky 1987), která jednak přichází s teoretickými otázkami po minulosti disciplíny, jednak skrze své nálezy relativizuje teoretický aparát současnosti. Historie vědy vlastního oboru nesmí klesnout a stát se „obchodem po zavíračce“ biografického čtení stop. Nemůže už být ,žádnou sbírkou biografií, a také žádným přehledem doktrín v prrírodopisném smyslu“. Spíše musí, jak píše Canguilhem (1979: 17), „rekonstruovat genealogii pojmů. Ale této genealogii je vlastní diskontinuita, stejně jako mendelovská dědičnost. Historie vědy musí být stejně náročná, stejně kritická jako věda sama.“ Pro systematický zájem o trvalou reflexi a kritiku je tedy třeba významových rámců, jež dávají současné odborné práci návod, pohled do minulosti, který má a priori zájem o teorii, ale také srovnává.

Vzájemný vztah systematiky a historie tak vede $\mathrm{k}$ nové odpovědi na otázku, proč $a k$ čemu je třeba provozovat historii sociologie. Běžný topos, že stálý kontakt $\mathrm{s}$ historií oboru rozšiřuje konceptuální spektrum možností současné sociologie, se dostává do závorek. „Nová““ odpověd’ staví tu obvyklou na hlavu. Historizování teoretického aparátu vzhledem k pluralitní krajině teorie účelné není, protože tak mohou být relativizovány současné možnosti a dřívější dodatečně získávány (sběrači ideji). Účelná je, protože hledání stop historické epistemologie umožňuje selektivnější chápání obíhajících konceptů. Ve studiu skladby 
a nikoli tónů se pak podaří lépe protř́dit ty, kterých je méně: například v pohledu na adekvátní chápání otázek, na co dnes vůbec mají (a mohou) odpovídat konkurenční přístupy. Novější přístupy, jak píše Wolfgang L. Schneider (2008: 17), „se doporučují většinou skrze změnu klíčových otázek“, pročež se historie oboru nedá „koncipovat jako lineární historie pokroku“ a právě tak je také ,jen zřídkakdy možné přímo srovnávat výkony jednotlivých přístupư“. Namísto kvantitativního rozšiřrení je pak nový cíl kvalitativní.

Ovšem důsledkem takového zájmu odvolávajícího se na teorii je, že z ideové a institucionální minulosti oboru ne vše může být zajímavé. Nelze pak objevit žádnou smyslem nasycenou historii vývoje lineárního toku idejí (kutilové identity) směřujícího do té - či oné - dnes obíhající teorie (Welz 1998a: 10-13). Namísto u jednotlivých biografických událostí nebo ideových analogií se př́stup pro sociologickou historii disciplíny, orientovanou na teorii, nachází u diskontinuit vývoje teorie. Právě pohled na nelogická napojení na dříve dominantní teorie vyvolává otázky, jež vyžadují sociologická vysvětlení. S Foucaultem by bylo možné říct: do analýzy musí být zapojeno historické vytváření diskursu (Foucault 1991, Frickel a Gross 2005, Fleck 2010). Opačně lze v současnosti probíraným teoriím lépe rozumět prostřednictvím kontextu jejich vzniku a původního vztahu k předmětu (naprríklad Šuber 2007, Wagner 2007); lépe, než se to může podařit jen logické analýze nebo výhradně formálnímu srovnávání teorií. Podle oddělení systematiky a historie sociologické teorie à la Merton je odborná minulost toliko prehistorií. V optice hledání stop se oproti tomu historie sociologie opět dostává ke slovu. Nebot' exaktně je třeba způsobilosti k historickému kontextualizováni formací vědění, aby nedošlo k převálcování domnělým chaosem současných pojmů (Lyotard 1986, Searle 1993-94), který výsledky výzkumu činí libovolnými z libovolných perspektiv.

\section{Závěr}

Teorie přinášejí do sociologie „,velké otázky“ (big questions). Současně integrují obor. Obepínají se okolo myšlenkových figur. Jejich obrysy, možnosti a hranice se odkrývají $\mathrm{v}$ rekonstrukci jejich geneze.

Je tedy jisté, že historicky-sociologické usouvztažnění sociologických teorií nemůže rozhodnout otázky jejich systematiky. Přece však k porozumění současným teoriím může zcela výrazně přispět ta, která je historická, protože počíá s kontingentními vlivy, a která je sociologická, protože pátrá po strukturách vědění v jejich sociálním kontextu. Může přispět více, než to dokáže formalistické srovnávání teorií na straně jedné a uplatnění minulosti oboru k pouhé podpoře identity nebo teorie prosté sbirání ideji na straně druhé. Historii chápané v komplementárním doplnění k teorii také už nejde o konstrukci nějaké ideově-historické vývojové linie a minulosti oboru. Pokud se teorie a historie mají vzájemně obohacovat a vztah jedné k druhé se nechce spokojit se separací a klasifikačním uvedením do klidu „klasiků sociologie“ (historická identita) na straně jedné nebo „hlavních děl sociologie“ (rozmanitost idejí) na straně druhé, pak vưdčí otázky pocházejí ze současné teoretické diskuze a zavádějí cesty zkoumání zpět ke švưm a diskontinuitám komplexní společenské vědy, ve kterých dnes relevantní myšlenkové figury a vzory zdůvodňování našly své vyústění (Welz 1998b, Barber 2006). Odpovídajícím způsobem už spojení systematických a historických perspektiv, jak 
je ted' vyzdvihováno dokonce v analytické filosofii (Bell a Vossenkuhl 1992: 7), nemusí být zakázáno (Camic 1997). Jejich souhra vyžaduje spíše selektivnější analýzu kolujících teorií.

Vedle své funkce v soustavné stabilizaci historické identity k účelům vzdělání a v nepřetržité, možnosti skýtající variaci svého arsenálu konceptů získává současná sociologická teorie svou nejvybranější úlohu v této selektivni funkci. Pokud směřujeme pohled vpřed na integrující účinek kognitivní formy disciplíny, posiluje sociologicko-historická analýza nikoli historickou identitu nebo institucionální zajištění sociologie, ale obnovuje její kognitivní autonomii a pritažlivost.

Z němčiny přeložil Pavel J. Michele.

\section{Literatura}

ALBROW, Martin. The Global Shift and its Consequences for Sociology. In GENOV, N. (ed.) Advances in Sociological Knowledge. Over half a Century.. Wiesbaden: Verlag für Sozialwissenschaften, 2004, s. 33-50. ISBN 978-3-8100-4012-1.

ALEXANDER, Jeffrey C. The New Theoretical Movement. In SMELSER, N. J. (ed.) Handbook of Sociology. Newbury Park: Sage, 1988, s. 77-101. ISBN 0-8039-2665-0.

BARBER, Michael. Philosophy and Reflection. A Critique of Frank Welz's Sociological and Processual Criticism of Husserl and Schutz. Human Studies, 2006, roč. 29, č. 2, s. 141-157. ISSN 0163-8548.

BELL, David; VOSSENKUHL, Wilhelm. Wissenschaft und Subjektivität. Der Wiener Kreis und die Philosophie des 20. Jahrhunderts. Berlin: Akademie, 1992. 288 s. ISBN 978-3-0500-2188-1.

BRAUN, Norman. Theorie in der Soziologie. Soziale Welt, 2008, roč. 59, č. 4, s. 371-395. ISSN 0038-6073.

BÜSCHGES, Günter; ABRAHAM, Martin; FUNK, Walter. Grundzüge der Soziologie. München/Wien: R. Oldenbourg, 1995. 267 s. ISBN 978-3-4862-2860-1.

BUTTERFIELD, Herbert. The Whig Interpretation of History. Harmondsworth: Penguin, 1931. $132 \mathrm{~s}$. ISBN 0-7135-0161-8.

CAMIC, Charles. The Utilitarians Revisited. American Journal of Sociology, 1979, roč. 85, č. 3, s. 516-550. ISSN 0002-9602.

CAMIC, Charles. On the Methodology of the History of Sociology. A Reply to Jones. American Journal of Sociology, 1981, roč. 86, č. 5, s. 1139-1144. ISSN 0002-9602.

CAMIC, Charles. The Matter of Habit. American Journal of Sociology, 1986, roč. 91, č. 5, s. 1039-1087. ISSN 0002-9602.

CAMIC, Charles. The Making of a Method. A Historical Reinterpretation of the Early Parsons. American Sociological Review, 1987, roč. 52, č. 4, s. 421-439. ISSN 0003-1224.

CAMIC, Charles. Introduction. Classical Sociological Theory as a Field of Research. In CAMIC, Ch. (ed.) Reclaiming the Sociological Classics. The State of the Scholarship. Malden (MA): Blackwell, 1997, s. $1-10$.

CANGUILHEM, Georges. Wissenschaftsgeschichte und Epistemologie. Gesammelte Aufsätze. Frankfurt/M.: Suhrkamp, 1979. 154 s. ISBN 978-3-5180-7886-0.

COHEN, Jere; HAZELRIGG, Lawrence E.; POPE, Whitney. De-Parsonizing Weber. A Critique of Parsons' Interpretation of Weber's Sociology. American Sociological Review, 1975, roč. 40, č. 2 , s. 229-241. ISSN 0003-1224.

COLLINS, Randall. The Sociology of Philosophies. A Global Theory of Intellectual Change. Cambridge (MA)/London: Belknap Press of Harvard University Press, 1998. 1098 s. ISBN 0-674-00187-7. 
DAHRENDORF, Ralf. Die bunten Vögel wandern weiter. In FRITZ-VANNAHME, J. (ed.) Wozu heute noch Soziologie? Opladen: Leske + Budrich, 1996, s. 31-36. ISBN 3-8100-1770-1.

DURKHEIM, Emile. Die Regeln der soziologischen Methode (frz. 1895). Frankfurt/M.: Suhrkamp, 1984. 256 s. ISBN 3518280643.

FEYERABEND, Paul. Wider den Methodenzwang. Skizze einer anarchistischen Erkenntnistheorie. Frankfurt/M.: Suhrkamp, 1976. 442 s. ISBN 978-3-5180-6007-0.

FLECK, Christian. Für eine soziologische Geschichte der Soziologie. Österreichische Zeitschrift für Soziologie, 1999, roč. 24, č. 2, s. 52-65. ISSN 1011-0070.

FLECK, Christian. Die Entwicklung der Soziologie in Österreich. In BIEGELBAUER, P. (ed.) Steuerung von Wissenschaft? Die Governance des österreichischen Innovationssystems. Innsbruck: Studienverlag, 2010, s. 259-296. ISBN 978-3-7065-4834-2.

FOUCAULT, Michel. Die Ordnung des Diskurses. Frankfurt/M.: Fischer, 1991. 54 s. ISBN 3-596-10083-6.

FRICKEL, Scott; GROSS, Neil. A General Theory of Scientific/Intellectual Movements. American Sociological Review, 2005, roč. 70, č. 2, s. 204-232. ISSN 0003-1224.

GOULDNER, Alvin W. Die westliche Soziologie in der Krise. Reinbek: Rowohlt, 2 sv., 1974. 610 s. ISBN 978-3-4995-5361-5.

HAMILTON, Richard F. American Sociology Rewrites Its History. Sociological Theory, 2003, roč. 21, č. 3, s. 281-297. ISSN 0735-2751.

HANSON, Norwood Russell. Patterns of Discovery: An Inquiry into the Conceptual Foundations of Science. Cambridge: Cambridge University Press, 1958. 240 s. ISBN 0-521-05197-5.

HECKMANN, Friedrich; KRÖLL, Friedhelm. Einführung in die Geschichte der Soziologie. Stuttgart: Enke, 1984. 152 s. ISBN 978-3-4329-4081-6.

HEGEL, Georg Wilhelm Friedrich. Phänomenologie des Geistes. Hamburg: Felix Meiner, 1952. 595 s. ISBN 978-0-1982-4597-1.

HEILBRON, Johan; MAGNUSSON, Lars; WITTROCK, Björn. (eds.) The Rise of the Social Sciences and the Formation of Modernity. Conceptual Change in Context, 1750-1850. Dordrecht: Kluwer, 1998. 308 s. ISBN 978-1-4020-0254-0.

HONDRICH, Karl-Otto; MATTHES, Friedhelm (eds.). Theorienvergleich in den Sozialwissenschaften. Darmstadt/Neuwied: Luchterhand, 1978. 367 s. ISBN 3-4727-5108-8.

HONEGGER, Claudia; WOBBE, Theresa (eds.). Frauen in der Soziologie. Neun Porträts. München: Beck, 1998. ISBN 3-4063-9298-9.

JONAS, Friedrich. Geschichte der Soziologie. svazek. 1: Aufklärung, Liberalismus, Idealismus, Sozialismus, Übergang zur industriellen Gesellschaft; svazek 2: Von der Jahrhundertwende bis zur Gegenwart. Opladen: Westdeutscher Verlag, 1981. ISBN 9783531220932.

JONES, Robert Alun. On Understanding a Sociological Classic. American Journal of Sociology, 1977, roč. 83, č. 2, s. 279-319. ISSN 0002-9602.

JONES, Robert Alun. The New History of Sociology. Annual Review of Sociology, 1983, č. 9, s. 447-469. ISSN 0360-0572.

KÄSLER, Dirk (ed.). Klassiker soziologischen Denkens, 1. svazek.: Von Comte bis Durkheim. München: C. H. Beck, 1976. 360 s. ISBN 978-3-447-04709-8.

KÄSLER, Dirk (ed.). Klassiker soziologischen Denkens, 2. svazek: Von Weber bis Mannheim. München: C. H. Beck, 1978. 280 s. ISBN 978-3-447-04709-8.

KÄSLER, Dirk. Max Weber. An Introduction to his Life and Work. Cambridge: Polity Press, 1988. 287 s. ISBN 978-0-2264-2559-7.

KÄSLER, Dirk. Guardians of Canonical Wisdom. Why Some of Us Care for the History of Sociology. Schweizer Zeitschrift für Soziologie, 1999, roč. 25, č. 2, s. 149-159. ISSN 0379-3664. 
KÄSLER, Dirk (ed.). Aktuelle Theorien der Soziologie. Von Shmuel N. Eisenstadt bis zur Postmoderne. München: C. H. Beck, 2005. 359 s. ISBN 3-406-52822-8.

KILMINSTER, Richard. The Sociological Revolution. From the Enlightenment to the Global Age. London/New York: Routledge, 1998. 221 s. ISBN 978-0-4150-2920-9.

KORTE, Hermann. Einführung in die Geschichte der Soziologie. Opladen: Westdeutscher Verlag, 1992. 216 s. ISBN 3-8252-8064-0.

KORTE, Hermann. Einführung in die Geschichte der Soziologie. 8. vydání, Wiesbaden: VS Verlag für Sozialwissenschaften, 2006. 563 s. ISBN 978-3-5311-4774-1.

KUHN, Thomas S. The Structure of Scientific Revolutions. Chicago: University of Chicago Press, 1962. 173 s. ISBN 978-0-226-45811-3.

LENSKI, Gerhard. Human Societies. A Macrolevel Introduction to Sociology. New York: Mc-Graw Hill, 1970. 529 s. ISBN 978-0-0703-7166-8.

LEPENIES, Wolf (ed.). Geschichte der Soziologie. Studien zur kognitiven, sozialen und historischen Identität einer Disziplin. 4 svazky, Frankfurt/M.: Suhrkamp, 1981a. 811 s. ISBN 978-3518570913.

LEPENIES, Wolf. Einleitung. Studien zur kognitiven, sozialen und historischen Identität der Soziologie. In LEPENIES, W. (ed.) Geschichte der Soziologie. Studien zur kognitiven, sozialen und historischen Identität einer Disziplin, svazek 1. Frankfurt/M.: Suhrkamp, 1981b, s. i-xxxv.

LORD, Jane T.; SANDERSON, Stephen K. Current Theoretical and Political Perspectives of Western Sociological Theorists. The American Sociologist, 1999, roč. 30, č. 3, s. 42-66. ISSN 0003-1232.

LOVEJOY, Arthur O. Die große Kette der Wesen. Geschichte eines Gedankens. Frankfurt/M.: Suhrkamp, 1985. 462 s. ISBN 3-5185-7734-4.

LUHMANN, Niklas. Soziale Systeme. Grundriß einer allgemeinen Theorie. Frankfurt/M.: Suhrkamp, 1984. 674 s. ISBN 3-518-28266-2.

LUHMANN, Niklas. Das Moderne der modernen Gesellschaft. In ZAPF, W. (ed.) Die Modernisierung moderner Gesellschaften. Verhandlungen des 25. Deutschen Soziologentages in Frankfurt am Main. Frankfurt a. M./New York: Campus, 1991, s. 87-108.

LYOTARD, Jean-François. Das postmoderne Wissen. Ein Bericht. Graz/Wien: Böhlau, 1986. 193 s. ISBN 978-3-2050-1307-5.

MACIONIS, John J. Sociology. 4. vydání, Upper Saddle River, JN: Prentice Hall, 1993. 716 s. ISBN 0-1304-0737-2.

MARGOLIS, Joseph. Donald Davidson's Philosophical Strategies. In GOULD, C. C., COHEN, R. S. (eds.) Artifacts, Representations and Social Practice. Essays for Marx Wartofsky. Dordrecht/Boston/London: Kluwer, 1994, s. 291-322. ISBN 0-7923-2481-1.

MERTON, Robert K. On the History and Systematics of Sociological Theory [německy 1981]. In On Theoretical Sociology. Five Essays Old and New. New York: Free Press, 1967, s. 1-37. ISBN 9780-0292-1150-2.

MERTON, Robert K. Social Theory and Social Structure. New York: Free Press, 1968. 702 s. ISBN 978-0-0292-1130-4.

MERTON, Robert K. Zur Geschichte und Systematik der soziologischen Theorie. In LEPENIES, W. (ed.) Geschichte der Soziologie. Studien zur kognitiven, sozialen und historischen Identität einer Disziplin. Bd. 1. Frankfurt/M.: Suhrkamp, 1981, s. 15-74. ISBN 3-518-07967-0.

MÖBIUS, Stephan; LOTHAR, Peter (eds.). Französische Soziologie der Gegenwart. Konstanz: UVK, 2004. ISBN 3-8258-0656-9.

MOZETIC, Gerald. Geschichte der Soziologie - quo vadis? Österreichische Zeitschrift für Soziologie, 1995, roč. 20, č. 4, s. 3-17. ISSN 1011-0070.

MÜNCH, Richard. Soziologische Theorie, Bd. 1: Grundlegung durch die Klassiker. Frankfurt/M./New York: Campus, 2002. 327 s. ISBN 3-593-37589-3. 
NEALON, Jeffrey; GIROUX, Susan Searls. The Theory Toolbox. Critical Concepts for the Humanities, Arts, and Social Sciences. Lanham, MD: Rowman and Littlefield, 2003. 217 s. ISBN 978-0-7425-1994-7.

PARSONS, Talcott. Some Problems Confronting Sociology as a Profession. American Sociological Review, 1959, roč. 24, č. 4, s. 547-559. ISSN 0003-1224.

PARSONS, Talcott. The Structure of Social Action [1937], 2 svazky. New York: Free Press, 1968. $470 \mathrm{~s}$. ISBN 978-0-0292-4240-7; 368 s. ISBN 978-0-0292-4250-6.

PARSONS, Talcott. Revisiting the Classics throughout a Long Career. In RHEA, B. (ed.) The Future of the Sociological Classics. London: George Allen \& Unwin, 1981, s. 183-194. ISBN 0043011373.

PEEL, J. D. Y. Two Cheers for Empiricism. Or, What is the Relevance of the History of Sociology to its Current Practice? Sociology, 1978, roč. 12, č. 2, s. 347-359. ISSN 0038-0385.

PLUMMER, Ken (ed.). The Chicago School: Critical Assessments. Vol. 1: A Chicago Canon? London: Routledge, 1997. 230 s. ISBN 0-415-11639-2

REICHENBACH, Hans. Der Aufstieg der wissenschaftlichen Philosophie. Braunschweig: Friedrich Vieweg \& Sohn, 1968. $370 \mathrm{~s}$.

RITZER, George (ed.). Metatheorizing in Sociology. Lexington/Toronto: New Lexington Press, 1992. 362 s. ISBN 978-0-387-32458-6.

RITZER, George. Sociological Theory. New York: McGraw-Hill, 2008. 784 s. ISBN 978-0-0735-2818-2.

RORTY, Richard. Philosophy and the Mirror of Nature. Princeton: Princeton University Press, 1979. 424 s. ISBN 0-691-02016-7.

SCHNEIDER, Wolfgang L. Grundlagen der soziologischen Theorie. Bd. 1: Weber-Parsons - MeadSchütz. Wiesbaden: VS Verlag für Sozialwissenschaften, 2008. 311 s. ISBN 978-3-5311-5829-7.

SEARLE, John R. The Mission of the University. Intellectual Discovery or Social Transformation? Academic Questions, 1993-94, roč. 7, č. 1, s. 80-85.

SKINNER, Quentin. Meaning and Understanding in the History of Ideas. History and Theory, 1969, roč. 8, č. 1, s. 3-53. ISSN: 1468-2303.

SKINNER, Quentin (ed.). The Return of Grand Theory in the Human Sciences. Cambridge: Cambridge University Press, 1985. 215 s. ISBN 978-0-5213-9833-6.

SOROKIN, Pitirim A. Contemporary Sociological Theories. Through the First Quarter of the Twentieth Century. New York: Harper \& Row, 1964. 783 s. (OCoLC)650026613.

ŠUBER, Daniel. Die soziologische Kritik der philosophischen Vernunft. Zum Verhältnis von Soziologie und Philosophie um 1900. Bielefeld: Transcript, 2007. 522 s. ISBN 978-3-8994-2727-1.

TURNER, Stephen P. Who's Afraid of the History of Sociology? Schweizerische Zeitschrift für Soziologie, 1998, roč. 24, č. 1, s. 3-10. ISSN 0379-3664.

TURNER, Stephen P. Many Approaches, but Few Arrivals. Merton and the Columbia Model of Theory Construction. Philosophy of the Social Sciences, 2009, roč. 39, č. 1, s. 174-211. ISSN 0048-3931.

VESTER, Heinz-Günter. Kompendium der Soziologie II: Die Klassiker.Wiesbaden: VS Verlag für Sozialwissenschaften, 2009. 225 s. ISBN 978-3-531-15804-4.

WAGNER, Gerhard. Eine Geschichte der Soziologie. Konstanz: UVK, 2007. 238 s. ISBN 978-3-8252-2961-0.

WALLERSTEIN, Immanuel. Differentiation and Reconstruction in the Social Sciences. A Paper Presented at ISA Research Council, Montreal, 1997.

WARTOFSKY, Marx. Epistemology Historicized. In SHIMONY, A., NAILS, D. (eds.) Naturalistic Epistemology. A Symposium of Two Decades. Dordrecht: D. Reidel, 1987, s. 357-374. ISBN: 978-9-0277-2337-6.

WEBER, Max. Die „Objektivität“" sozialwissenschaftlicher und sozialpolitischer Erkenntnis [1904]. In Gesammelte Aufsätze zur Wissenschaftslehre. Tübingen: Mohr, 1985, s. 146-214. ISBN 3-16-544996-1. 
WEINGART, Peter. Anything Goes - rien ne va plus. Der Bankrott der Wissenschaftstheorie. Kursbuch, 1984, č. 78, s. 61-75. ISSN 0023-5652.

WELSCH, Wolfgang. Unsere postmoderne Moderne. Weinheim: VCH, 1987. 344 s. ISBN 3-527-17584-9.

WELZ, Frank. Einleitung. Soziologische Theorie und Geschichte. In WELZ, F., WEISENBACHER, U. Soziologische Theorie und Geschichte. Opladen/Wiesbaden: Westdeutscher Verlag, 1998a, s. 9-32. ISBN 978-3-531-13347-8.

WELZ, Frank. Die phänomenologische Theorie vor der Geschichte. In WELZ, F., WEISENBACHER, U. Soziologische Theorie und Geschichte. Opladen/Wiesbaden: Westdeutscher Verlag, 1998b, s. 134-154. ISBN 978-3-531-13347-8.

WELZ, Frank. 100 Years of Indian Sociology. From Social Anthropology to Decentring Global Sociology. International Sociology, 2009, roč. 24, č. 5, s. 1-21. ISSN 0268-5809.

\section{Autor}

Frank Welz vystudoval sociologii, filozofii, psychologii a historii na Univerzitě AlbertaLudvíka ve Freiburgu, od roku 2006 vyučuje na Univerzitě v Innsbrucku. Je mluvčím Teoretické sekce Evropské sociologické asociace (European Sociological Association) a viceprezidentem rakouské Sociologické společnosti (Österreichische Gesellschaft für Soziologie). Věnuje se především sociologické teorii, sociologii práva, historii sociologie a začleňování historické epistemologie do sociologie. Je autorem a editorem řady knih a článků, mimo jiné Law and Modernity: A Metacritique of the Kantian Foundations of Social Science (2012), Moral und Recht im Diskurs der Moderne. Zur Legitimation gesellschaftlicher Ordnung (ed. s G. Duxem, 2001), Kritik der Lebenswelt (1996), publikuje např́klad v časopisech International Sociology a Soziologie.

Kontakt: frank.welz@uibk.ac.at 